Article

\title{
Managing the Transition towards Circular Metabolism: Living Labs as a Co-Creation Approach
}

\author{
Libera Amenta $1,2, *$, Anna Attademo ${ }^{2}$, Hilde Rem $\varnothing y^{3}$, Gilda Berruti ${ }^{2}$, Maria Cerreta ${ }^{2}$, Enrico Formato ${ }^{2}$, \\ Maria Federica Palestino ${ }^{2}$ and Michelangelo Russo ${ }^{2}$ \\ ${ }^{1}$ Department of Urbanism, Faculty of Architecture and the Built Environment, Delft University of Technology, 2628 Delft, \\ The Netherlands; E-Mail: I.amenta@tudelft.nl \\ 2 Department of Architecture, University of Naples Federico II, 80134 Naples, Italy; E-Mails: libera.amenta@unina.it (L.A.), \\ anna.attademo@unina.it (A.A.), gberruti@unina.it (G.B.), maria.cerreta@unina.it (M.C.), e.formato@unina.it (e.f.), \\ palestin@unina.it (F.P.), russomic@unina.it (M.R.) \\ ${ }^{3}$ Department of Management in the Built Environment, Faculty of Architecture and the Built Environment, Delft University \\ of Technology, 2628 Delft, The Netherlands; E-Mail: h.t.remoy@tudelft.nl
}

* Corresponding author

Submitted: 1 April 2019 | Accepted: 9 September 2019 | Published: 27 September 2019

\begin{abstract}
Resource consumption and related waste production are still rapidly increasing all over the world, leading to social and environmental challenges and to the production of the so-called 'wastescapes'. Peri-urban areas-in-between urban and rural territories - are particularly vulnerable and prone to develop into wastescapes because they are generally characterised by mixed functions and/or monofunctional settlements, as well as by fragmentation in a low-density territory that is often crossed by large infrastructure networks. Moreover, peri-urban areas are generally the selected locations for the development of plants for waste management. In this way, they are crossed by waste flows of a different nature, in a landscape of operational infrastructures and wasted landscapes. Implementing Circular Economy (CE) principles, interpreting waste and wastescapes as resources, is a way to significantly reduce raw material and (soil) resource consumption, improving cities' metabolism. A circular approach can positively affect the spatial, social and environmental performances of periurban areas. However, the transition towards a CE presents many challenges. This article outlines an approach to address these challenges, presenting a co-creation process among researchers, experts and stakeholders within Living Labs (LLs) processes. LLs are physical and virtual spaces, aiming at the co-creation of site-specific eco-innovative solutions (EIS) and strategies. In the LLs, public-private-people partnerships are developed by applying an iterative methodology consisting of five phases: Co-Exploring, Co-Design, Co-Production, Co-Decision, and Co-Governance. This article presents a case study approach, analysing the co-creation methodology applied in two peri-urban living labs, located in the Metropolitan Areas of Naples (Italy) and Amsterdam (The Netherlands), within REPAiR Horizon2020 research project.
\end{abstract}

\section{Keywords}

circular economy; circular metabolism; circular waste management; co-creation; co-governance; living labs; peri-urban living labs; resource scarcity; waste management; wastescapes

\section{Issue}

This article is part of the issue "Facilitating Circular Economy in Urban Planning", edited by Hilde Remoy (Delft University of Technology, The Netherlands), Alexander Wandl (Delft University of Technology, The Netherlands) and Denis Ceric (Polish Academy of Sciences, Poland).

(C) 2019 by the authors; licensee Cogitatio (Lisbon, Portugal). This article is licensed under a Creative Commons Attribution 4.0 International License (CC BY). 


\section{Introduction}

This article is based on the European Horizon 2020 research project "REPAiR: REsource Management in Peri-urban AReas: Going Beyond Urban Metabolism", interpreting waste and wastescapes as resources for sustainable regeneration. In this project, eco-innovative solutions (EIS) and strategies for waste and wastescapes are developed in co-creation workshops implemented in Living Labs (LLs).

Nowadays, urban and territorial metabolisms are mainly linear. They are characterised by a high degree of resource depletion and outbound loss. This is leading to resource consumption on one hand-related to scarcity-and to severe waste accumulation on the other. In this context, scarcity should be considered at two different levels. Firstly, related to the limited availability of raw materials; secondly, to the condition of the places where the availability of virgin land for agriculture is becoming scarce due to soil pollution, high imperviousness, abandonment, vacancy and decay. To overcome this situation, a transition from a linear to a circular model of growth (EC, 2014; Ellen MacArthur Foundation, 2015a; European Commission, 2018) becomes the priority.

Considering waste as an innovative resource supports the initiatives of the European Commission, in order to reduce waste flows for the year 2020 (EC, 2010; EC Horizon 2020, 2019; EEA European Environment Agency, 2015). Implementing Circular Economy (CE) principles facilitates sustainable urban growth, reducing possible negative environmental impacts and stimulating social inclusion (REPAiR, 2017d; UNEP, 2011).

CE models do not generally tackle the reuse of land and are mostly focused on material, organic and mineral resources (Ellen MacArthur Foundation, 2015a, 2015b; Williams, 2019). In this perspective, this article presents research on circular reuse of wasted land resources, namely wastescapes (Amenta \& Attademo, 2016; Amenta \& Formato, 2016; Amenta \& van Timmeren, 2018; Cerreta, Inglese, \& Mazzarella, 2018; Formato, Attademo, \& Amenta, 2017; REPAiR, 2017c, 2018c; Rigillo et al., 2018). The latter are interpreted as innovative resources to be reused to implement more sustainable, inclusive and circular urban and territorial metabolisms, decoupling economic growth from resource consumption and environmental depletion (UNEP, 2011).

Wastescapes have a twofold meaning. Firstly, they are defined as "drosscape" (Berger, 2006a, 2006b), which can be polluted lands, brownfields or "land in limbo' in a waiting condition (de Martino, 2016), and more generally they can be the results of simultaneous urban growth and shrinkage (Oswalt \& Rieniets, 2006). Second, wastescapes are defined as "operational infrastructure of waste" which constitute new waste geographies or the infrastructures of waste (Brenner, 2014; de Leo \& Palestino, 2017; O'Shea, Hegeman, \& Bennett, 2016; REPAiR, 2018c) being the new landmarks of contemporary territories.
A circular regeneration of wastescapes involves different dimensions such as environment, biodiversity, society, quality of life, accessibility and infrastructure (Amenta \& van Timmeren, 2018). For this reason, the circular processes, which involve the regeneration of wastescapes, tend to be holistic and non-sectorial. Moreover, they include a focus on short-term and placebased EIS, as well as on long-term strategies, crossing different scales and involving different types of stakeholders. Moreover, EIS and strategies for the regeneration of wastescapes mix bottom-up and top-down approaches by also involving different stakeholders simultaneously.

The innovative approach related to the regeneration of wastescapes uses a new lens which is useful to observe and interpret the contemporary landscape. This new perspective focuses on relations among different territories, i.e., among people and their living environment. In this way, the regeneration of wastescapes involves a comprehensive approach which investigates the possibility of reconnecting formerly fragmented wastescapes in a wellconnected network of regenerated lands. This is overcoming the common way of approaching brownfield regeneration, which is usually referred to as the mere implementation of technical solutions in a confined space or territory.

Moreover, the regeneration of wastescapes, in line with the principles of $\mathrm{CE}$, is reversing the evaluation of wasted places that are no longer perceived as problematic areas but as resources and potential for improving the quality of life in the territories that are the subject of this study.

Metropolitan areas are currently challenged by complex environmental problems, often interrelated with social issues, especially in fragile environments worldwide, as in peri-urban areas. Peri-urban areas are typically spatially fragmented (Wandl, Nadin, Zonneveld, \& Rooij, 2014) and have a higher presence of wastescapes than other urban areas (EC, 2016). Moreover, they are typified by systemic challenges. Spatial fragmentation is interlinked to social vulnerability due to lack of accessibility to spatial capital (Secchi, 2013), for example in the case of polluted or fenced areas.

It is crucial to reflect on this extensive global crisis and socio-spatial inequalities to address "the new urban question" (Secchi, 2010, 2013). Spatial injustice, unequal access to opportunities, and environmental vulnerability are creating a demand for planners to design devices that are able to address inequalities and overcome social and environmental challenges.

The traditional model of planning must be redefined in consideration of the redefinition of welfare policies in response to the global crisis. Furthermore, the search for transparent and inclusive decision-making processes and the extension of involved actors can be at the core of an expansion of the democratic conditions of management, accessibility and use of resources (Russo, 2017).

Innovation in urban planning calls for innovation in the methodologies used, as the demand for new ac- 
tors and new challenges implies the flexibility of devices and tools that cannot be achieved using old-school paradigms and settings (Attademo, 2015).

The shallow involvement of generic stakeholders in urban transformations is to be avoided in order to establish cooperation between actual end-users, working in a "user-driven open innovation ecosystem" (EC, 2009) with common goals, and various competences (Innovation Alcotra, 2013).

In this article, the activities developed in two pilot laboratories located in the Metropolitan Areas of Naples (MAN) and Amsterdam (AMA) are presented. These specific cases are relevant because of the variety of challenges they encompass. In the MAN, between 1994 and 2009, the regional Waste Emergency and the more recent phenomenon of the Land of Fires increased the level of environmental damage (Berruti \& Palestino, 2019; Palestino, 2015). Both crises are dependent on government inabilities and the poor governance model in use (REPAiR, 2017b). Acting as a driver for further improper use of land and non-regulation, the two environmental emergencies contributed to turning open spaces and agricultural plots into waste landscapes (Berruti \& Palestino, 2017). In this context, circularity principles are far from being applied (Berruti \& Palestino, 2018). Conversely, in the Amsterdam context, the reuse of land is already an implemented tool for combining urban regeneration and circular metabolism. The existing perception is already intrinsically connected to the new urban question and its demands. CE principles are already widely accepted and shared, however, the majority of initiatives are merely focusing on the recycling principle of $C E$, leaving aside the principles of reduction and rethinking (PBL Planbureau voor de Leefomgeving, 2018), which would entail a completely different kind of growth (Russo, 2014).

The methodology explained in the following paragraphs reflects these asymmetries. The case study approach allows the exploration of complex issues in reallife settings, as researchers have established an openprocess of learning by doing, working on potentials solutions for case studies, by being flexible and open to hybridise their original mindsets (REPAiR, 2018b).

Thus, this article-organised in five sections-begins by defining an approach to address the challenges for the transition towards a more CE by outlining the cocreation approach implemented in two Peri-Urban Living Labs (PULLs) in the MAN and the AMA (in section two). Secondly, in section three, it explores differences and similarities among the two approaches implemented in the abovementioned case-studies, focusing specifically on how EIS and strategies are developed within each Lab. In section four the application of a metabolic perspective to reinterpret the peri-urban areas of the two case studies is discussed. In this way, this research links the study of the metabolic flows within the urban and peri-urban landscape with the territorial condition of wastescapes. Finally, in section five, the lessons learned on institutional and social innovation, wastescape definition and regeneration, and circularity are outlined for both case-studies.

\section{Methodology and Approach}

\subsection{PULLs and Decision Support Tools in Two Case Studies across Europe}

In this research, the complexity of waste management in peri-urban areas is unpacked and articulated within LL environments. LLs are case-specific approaches for developing (eco)innovations, combining planning and design (Cerreta \& Panaro, 2017a, 2017b; Concilio \& Rizzo, 2016). This requires a versatile methodology that is flexible and adaptive to the different local contexts (REPAiR, 2017d).

In PULLs-a place-specific variation of urban LLsconceived as new forms of good local governance are implemented in the development of innovative services and processes for circular peri-urban regions. PULLs are interpreted as innovative approaches for effective planning strategies and inclusive decision models (ENoLL, 2016; ENoLL \& World Bank, 2015).

Generally, in urban LLs, the innovation process is assured thanks to co-creation activities (Steen \& van Bueren, 2017). By co-creation, unusual and new ideas can be developed thanks to the presence and the coworking of several stakeholders at the same time and in the same place. They can help identify problems and challenges, desired trajectories that are seen as feasible solutions and can be followed in order to deal with complex systems. At the same time, PULLs rely on Public-Private-People-Partnerships (Innovation Alcotra, 2013), as citizens and local associations are considered to be an important source for the innovation process (REPAiR, 2018b).

Central aspects for developing a PULL are regional context and place-specificity, data, models, and the availability of information on stakeholders (REPAiR, 2018b). This research places this framework in relation with Steinitz's Geodesign approach (EC, 2016; Steinitz, 2012). Based on six representation models, geodesign questions are combined with phases of the PULL, as described below, providing a methodological structure to the activities.

In general, co-creation processes implemented in LLS differ case by case and are site-specific, depending on the different stakeholders involved in the general decisionmaking process, as well as how they can contribute. The LL co-creation process aims at assuring larger participation and cooperation of local stakeholders who are actively involved in the decision-making process for the regeneration of the selected peri-urban areas. It follows that the outcomes of the co-creation workshops implemented in LLs-the EIS and strategies-are the result of wide participation of actors since the first phase of the idea development. In this way, the ownership of the project/solution ideas is shared among several stakehold- 
ers and better management of its implementation can be assured. For instance, in the case of Naples, citizens belonging to local citizens' associations have been involved in the co-creation workshops of the REPAiR PULL. In this way, the identification of EIS for the regeneration of polluted wastescapes was not just limited to the technical remedy for soil reclamation based on phytoremediation, but it became a wider project including the social and cultural dimensions. This was done by identifying traditional local crops as the most appropriate species for this purpose (e.g., hemp), the cultivation of which could also contribute to the implementation of traditional cultivation in the territory, and eventually bring opportunities for new jobs.

Furthermore, the involvement of local communities has shown to positively influence citizens by having them struggle together in order to identify solutions and strategies for achieving the sustainability of their territories, resulting in increased trust in their institutions.

The implementation of co-creation processes in LLS can help to overcome institutional lock-in situations. Indeed, in LLs, the different stakeholders cooperate to identify strategies that can help to create new bridges between roles and points of view which normally function in a sectorial manner. For instance, in the case of Naples, one of the most fruitful experiments of interaction among stakeholders was conducted in one of the PULL workshops in the MAN in a group working on homogeneous ecological islands. The goal was to establish an integrated collection and reuse centre for construction and demolition waste. The idea was to create a service for the city located on land that had been confiscated from organised crime. The objective of this group was the reduction of waste, favouring the re-use of durable goods while limiting illegal dumping along the peri-urban infrastructures. This action met the goals of a project proposed by the Regional Waste Prevention Plan of the Campania Region of 2013 (called “CIRO" project, from the Italian acronym for "integrated centre for optimal reuse"), but not included in the general provisions of the Regional Waste Law (no. 14/2016). After the work done within in the REPAiR PULL, these CIRO areas have been regulated by the Regional Law no. 29 of 2018 and have returned to regional attention, after having been overlooked for a long time. Even if such integrated centres have not been the object of the EIS developed by this research project, it can be stated that the activities of the PULL accelerated a regional policy process involving the topic of circularity, forgotten spaces, discarded objects, and policies that have momentarily been put aside.

\subsection{The Phases of Co-Creation}

One of the first LL methodologies is the FormIT (Ståhlbröst \& Holst, 2012), an iterative method developed to suit and support LL activities. An evolution of FormIT methodology, combined with the 4Co model-CoDesign, CoDecide, CoProduce, CoEvaluate
(Pollitt, Bouckaert, \& Loeffler, 2006)-was already tested in some experiences of LLs (Cerreta \& Panaro 2017a, 2017b). It is the basis for the Co-creation process implemented in REPAiR PULLs, based on the five iterative phases listed below (see Figure 1; REPAiR, 2017d):

- Co-Exploring;

- Co-Design;

- Co-Production;

- Co-Decision;

- Co-Governance.

The Co-Exploring phase (Phase 1) deals with two of the Geodesign models. Firstly, there is the Representation Model, tackling the definition of a common understanding of the territory, developed with the collaboration of all the researchers, stakeholders and experts identified and involved in the project. Secondly, the Process Model is investigated. Key resource flows are selected through the definition and mapping of material flows and waste management system. The thematisation of the main challenges/problems and objectives is eventually conducted as the end of phase one.

The Evaluation Model and Change Model are the objects of the Co-Design phase (Phase 2). Local teams conduct research and experiments to assess the status quo, further identifying specific challenges and problems in order to define EIS and their functioning.

Phase 3, Co-Production, addresses the Change Model, deepening the understanding and development of EIS and Eco-Innovative strategies. This phase is crucial for the transition to more circular models in peri-urban areas and for boosting the innovation processes.

Phase 4, Co-Decision, explores the Impact Model, evaluating EIS efficiency and their transferability to other contexts. In addition to that, research teams should deal with the Decision Model. This model coincides with the documentation of agreements and conflicts between different interests and groups of decision-makers involved in the project. The ultimate goal becomes to trigger future local development and influence the decisionmaking process through co-creation.

Phase 5 of the PULL consists in Co-Governance. This is related to the Decision Model of the Geo-design framework and it is about delivering decision-making models based on co-creation and making them transferable to further cases.

\subsection{The Case-Study Approach as a Method: MAN and AMA as Fields of Action}

The case study approach helps in decoding methods from experiences, reflecting on the differences in challenges, data sources and then in potential results.

Since 2016, the PULLs of Amsterdam and Naples have been carrying out their experimentations. Accordingly, based on the difference in territorial challenges and in stakeholder's awareness, the methodology has been 


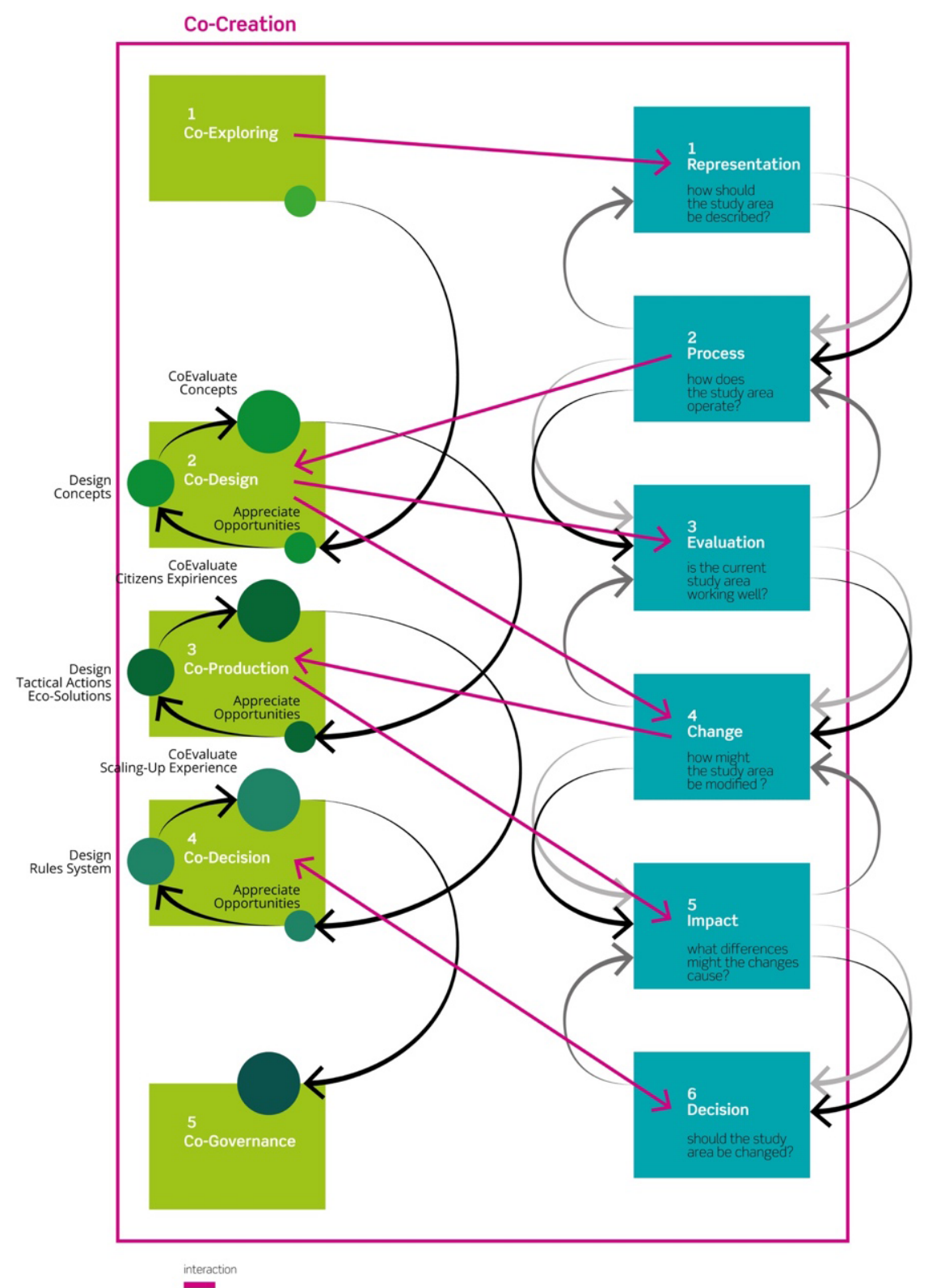

Figure 1. LL \& Geodesign interaction: REPAiR methodological proposal. Source: REPAiR Unina Team.

slightly adjusted during the process, which shows the implementation of an open and place-based process. In the co-exploration phase, two large mapping experimentations were relevant in both cases. The first mapping experimentation was referred to the selection of the group of relevant stakeholders. The elaborated selection evolved during this process in a recursive way. The second extensive mapping experimentation referred to the definition of the project focus area. Each case-study area definition has been unique, depending on the local context, the specific challenges and thematic and spatial coverage (REPAiR, 2017c). Included in the mapping exercise on the focus area, the research project followed an iterative process to identify, categorise and select wastescapes, with the collaboration of different types of stakeholders.
In both cases, the involvement of students in the spatial analysis has been a crucial element. They have contributed to basic research activities and they worked on real-life projects on multidisciplinary teams.

\subsubsection{The MAN Case-Study and the Definition of Its Boundaries}

The MAN includes 92 municipalities in a total area of 1171 square kilometers and inhabited by about 3 million people. The definition of the area has been carried out in the co-exploration phase, among researchers and selected stakeholders. The defined area was a physical, socio-ecological and administrative sample for the matter of waste and resource management. The guiding principles in the selection of the focus area (Figure 2; REPAiR, 


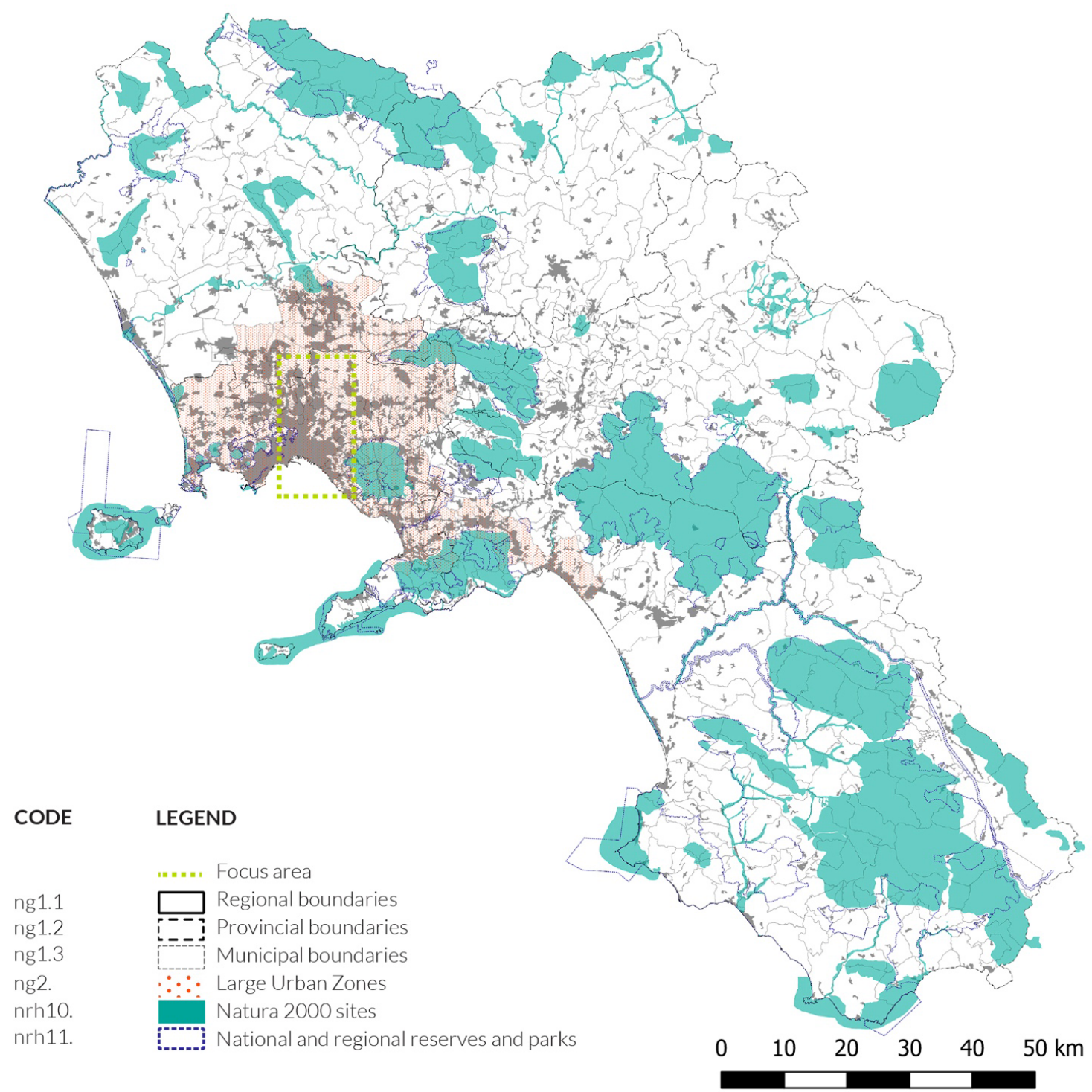

Figure 2. Administrative, demographic and planning issues. Pilot case of Naples. Source: REPAiR (2018c); map by REPAiR UNINA Team.

2018c) were defined as follows (REPAiR, 2017b):

- The connection with the area of the waste crisis in Campania Region, the Land of Fires;

- The ATOs' (Optimal Territorial Area; in Italian, the Ambito Territoriale Ottimale) boundaries, defined for the waste management by Campania Regional Authority;

- The high amount and variety of wastescapes.

The basic idea was to define the appropriate scale to deal with specific urban issues. Moreover, the definition of boundaries and scales of intervention became a negotiation point among participants and administrations in the PULL, in order to foster the debate on critical conditions that affected territories. In particular, the selection of a sample area (composed of five municipalities, characterised by similar problems and challenges) allowed the combination of several layers of spatial, socio-economic and material flow information in an iterative and discursive process, stimulated by stakeholder's perspectives. Research groups developed spatial analysis on sample areas in parallel to PULLs activities. Participants-including local citizens' associations, researchers of the University of Naples Federico II, Regional and Municipal Authority representatives-co-created a map of wastescapes for the case study, in which layers of spatial information, landscape perceptions, as well as material flow analysis are overlapped.

\subsubsection{The AMA Case-Study and the Definition of Its Boundaries}

The AMA consists of the city of Amsterdam, the provinces of North Holland and Flevoland with $36 \mathrm{mu}-$ nicipalities, and a population of over 2.4 million inhabi- 
tants. AMA Central Administration has administrative responsibility for the area. In the AMA, the focus area was defined starting with an analysis of key challenges for developing a more CE in peri-urban areas in the region, and an analysis of key resource flows. Based on that, the focus area was defined as the three 'main ports' in the region: 1) the Amsterdam North-West urban docklands (key areas with circular urban developments), including the ljmuiden port area (wastescapes and the port); 2 ) the Schiphol airport area (airport and the Valley CE initiative); and 3) South-East with the Greenport Aalsmeer (agricultural production in greenhouses and flower trad- ing; see Figure 3). The stakeholders involved in the Amsterdam PULL workshops were very diverse. Among them, there were Municipalities (Haarlemmermeer; Amsterdam), the Amsterdam Economic Board, TU Delft researchers, experts on CE (e.g., EVOLV), hogeschool, AMS Institute, professional firms, Waste Team city of Amsterdam, and so on.

\subsection{How to Develop EIS in MAN and AMA}

The experimentation in the PULLs involved the definition and implementation of eco-innovation (EC, 2012).

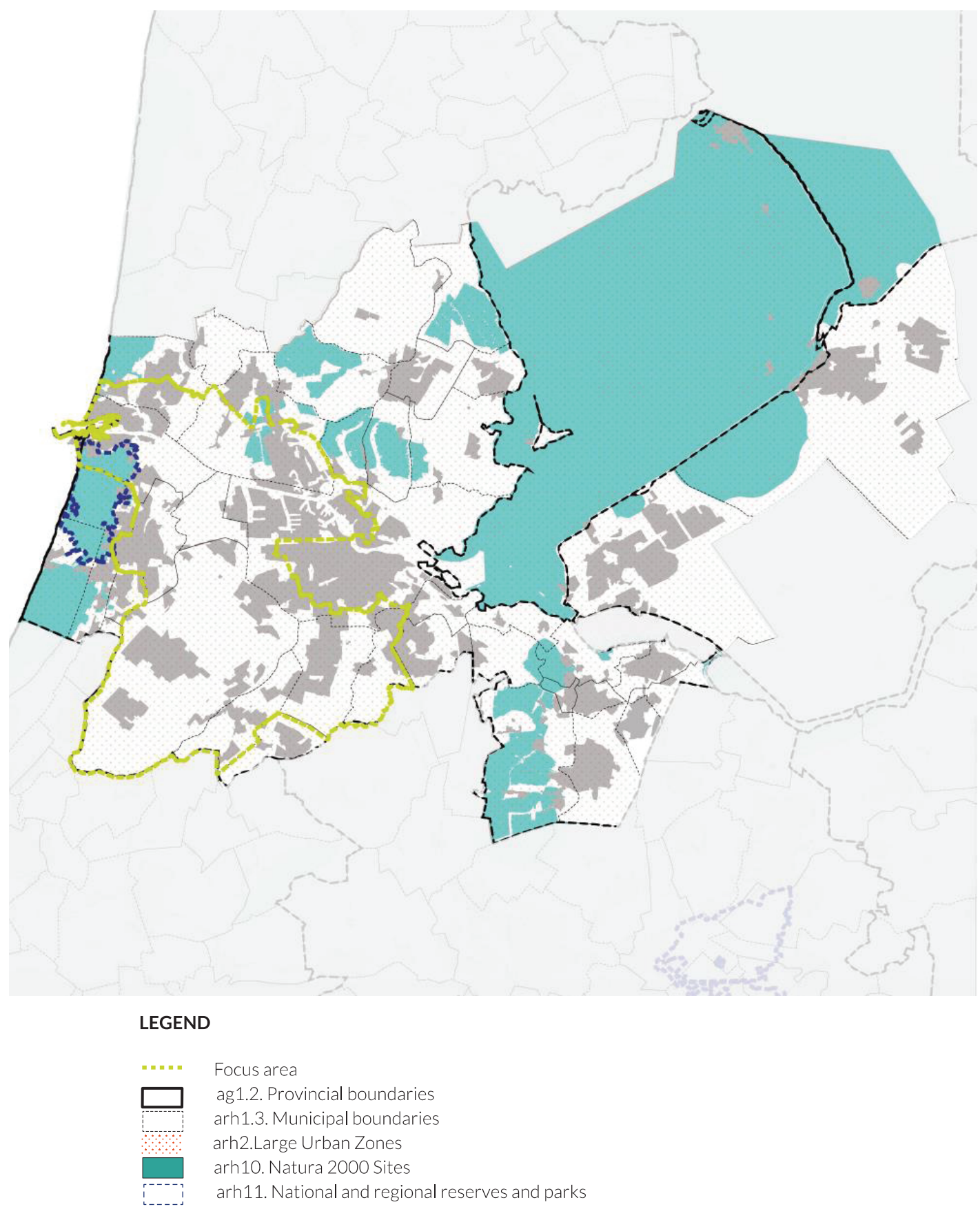

Figure 3. Administrative, demographic and planning issues. Pilot case of Amsterdam. Source: REPAiR (2018c); map by REPAiR TUDelft Team. 
Research teams combined this concept with the contextual knowledge developed in PULLS, eventually defining it as a place-based, processual and systemic tool for periurban areas. The PULLs must problem-solve and deal with innovation (van de Ven et al., 2009), working in a dimension where the problems and objectives are well defined (as an outcome of the work of the PULLS) but the solutions are yet to be defined.

An eco-innovative strategy has been defined as "an alternative course of action aimed at addressing both the objectives and challenges identified within a PULL and develop a more CE in peri-urban areas" (REPAiR, 2018a, p. 11). Then, a strategy can be composed of a systemic integration of two or more EIS.

The co-creation of EIS in pilot cases has been developed in a contextual process which is the most relevant element of innovation, more than the results themselves (Dente \& Coletti, 2011). The definition of EIS follows a circular and multi-scale process. EIS are place-based and depend on local, regional and national policies, as well as managerial ability, economic or financial specificities, and administrative capacity. At the same time, EIS has the ambition to be transferable to other case studies, where the contextual conditions can change. Then, the elementary EIS can be re-assembled in spatial strategies (and streamlining of flows) which are different case by case, since they depend on the local conditions, as the debate in each PULL could clarify throughout the project.

\subsection{Steps of Interaction with Stakeholders in the MAN and AMA PULLS}

Ten PULL workshops were organised in the MAN. In the first four PULLs, participants included representatives of regional, metropolitan and local governments, policymakers, waste management administrators, local companies' representatives and researchers. From the fifth PULL event on, social organisations and active citizens were also involved.

In the beginning, PULL events had as their main objective to build a shared knowledge on CE objectives between stakeholders and researchers. Then, they focused on constructing knowledge respectively on organic and construction and demolition waste. During the first PULL events, participants identified critical wastescapes in a collaborative process and they collectively updated the wastescape map and discussed its legend. Later on, the focus was on developing EIS. Thus, participants decided to divide themselves into three worktables. For each worktable, there were a leader, a facilitator and a Regional officer.

An interesting discussion began on the current possibility of funding specific actions. Participants also filled in a form on the proposed actions, identifying who was available to support them and interested in collaborating. The prioritisation of actions was included in the form.

The final PULL events focused on the report on the work that was carried out by local groups and the im- provement of the proposed solutions by the research group, stimulated by the visualisation of waste flows through the Geo-Design platform, under construction within the project.

The approach was the same in MAN and AMA. However, in the AMA, a series of three integrated PULL workshops were organised. The workshops focused on first identifying the challenges to a CE in the AMA, second, defining the objectives of the different stakeholders, and finally, developing EIS to respond to objectives and challenges. The fourth PULL workshop was organised as several small workshops, specifically focusing on developing EIS responding to each specific objective that was defined in the earlier workshops.

\section{Differences and Similarities between Case Studies: MAN and AMA}

\subsection{EIS in the MAN and AMA and the Differences in the Approach}

Before actually designing EIS, still in the co-exploration phase, challenge trees were used to define challenges and formulate objectives and directions for solutions in both cases. Working in small groups during the PULL workshops ( 3 to 5 participants) stimulated the participants to come up with concrete solutions.

At the start of the co-design phase, EIS coming from literature or defined by common discussions were presented in PULL events in both pilot cases. Then, both cases started a co-creation process with some differences due to stakeholder's awareness and the challenges emerged in the co-exploration phase.

In the MAN, three worktables focused respectively on three territorial strategies, as a starting point for testing preliminary EIS. Then, the researchers selected solutions to be further developed among the wider number of actions coming from the worktables. The MAN case-study considered the pressure of flows in spatial terms, on general peri-urban landscapes and especially on wastescapes. Furthermore, in order to facilitate interaction among local stakeholders, it was considered useful to work on a sample of the focus area, pointing out on the one hand current critical conditions, and on the other hand actual competences to implement solutions, leading to the development of place-based territorial strategies, in which eco-innovative actions can be distinguished.

In the AMA, EIS were developed for the flows of construction and demolition waste and food waste, and for wastescapes. In the co-exploration phase, the first mapping exercise was done to develop a common understanding of the territory, contributing to the representation model. Henceforth, challenges were defined for developing a $C E$ in the $A M A$, defining the key resource flows to focus on. Based on this, objectives were developed for implementing CE solutions in the AMA. The objectives were discussed in interviews with AMA stakeholders and in a follow-up PULL workshop. 
The results formed input for the representation and the process models. Then, in the co-design phase, the challenges and objectives were further detailed, and draft EIS were developed as a response to the challenges. In this phase, stakeholders were asked to rank the objectives and the expected impact of the developed solutions. Henceforth, in the co-production phase, a set of solutions were selected for further detailing based on the solutions that were developed and their expected impact. In this phase, a series of expert meetings were held, in which EIS were developed to be eventually assessed on sustainability and implemented in the change model. The solutions were detailed to provide input to the impact models, evaluating the efficiency of the EIS.

\subsection{Styles of Interaction: MAN and AMA}

From the initial survey to the PULL workshops, noted differences in interactions between Amsterdam and Naples emerged. Differences started from the composition of the public taking part in the PULLs to the methodology adopted to build the EIS.

In Amsterdam, participants in the PULLs were essentially experts, researchers, key stakeholders, companies and designers. In Naples, on the contrary, in addition to the public sector and a limited number of companies, many social organisations and civic groups have been involved. These differences led to different strategies in order to achieve the research objectives and the need to adapt the proposed methodologies to facilitate the involvement of the actors and the decisionmaking process.

The method used for the prioritisation of objectives is Soft Delphi (REPAiR, 2017a), which is productive for a public mainly composed of experts, but hardly applicable in the presence of a mixed public with a high percentage of social groups and organisations.

Amsterdam used questionnaires before and after the PULL workshops in order to assess the effectiveness of the meetings. In Naples, questionnaires were also used to collect information from participants in the PULLs on specific subjects.

The same differences apply to how EIS are developed. In Naples, they have been conceived as site-specific in the PULLs, then studied and improved by researchers, public sector officials and companies. In Amsterdam, after a developing and selection process, solutions were improved and adapted to the Amsterdam focus area. Although through different processes, in both Naples and Amsterdam, spatial analysis, material flow analysis and actor analysis were combined in the design of EIS.

\section{Discussion}

\subsection{From Wastescapes to Regenerative-Scapes}

This research applies a metabolic perspective to reinterpret the variety of fragile urban and peri-urban areas in two case studies in Europe, in Naples and Amsterdam. In particular, in the case of Naples, this research investigates the waste flows regarding Construction and Demolition Waste, and Organic Waste. In the case of Amsterdam, the flows of Construction and Demolition Waste and Food Waste are deepened. Furthermore, in both cases, this research studies the spatial effects of waste flows on the landscape, as well as the life cycle of the territories which in some cases can assume the appearance of wastescapes.

In the case of Naples, there was the need to investigate the topics related to the specific waste flows. The latter have been identified separately in separate PULL workshops with experts in the fields. This was also necessary because of the different stakeholders involved which, in the case of Construction and Demolition Waste, are mostly small and medium enterprises, and in the case of the Organic Waste are mostly the Campania Region Authority and the interested municipalities.

Conversely, in the case of Amsterdam, the different flows have been investigated in the same PULL workshop, where different sub-groups were organised in worktables and the experts involved had the opportunity to cocreate together with other stakeholders.

In both cases, all of the material flows are intertwined in the landscape, and particularly in what are defined as wastescapes.

Through co-design applied in PULLs, this research allows moving towards a more $\mathrm{CE}$, implemented thanks to new governance models. Wastescapes are the results of the operationalisation of linear urban metabolism. In this context, they can be the places that can host stakeholders when carrying out co-creation initiatives, defining a socio-technical domain.

PULLs activities configure a sort of community metabolism that arises as a vibrant response to the criticality of dissipation and abandonment, proposing innovative forms of urban recycling. The analysis of the spatial configuration and related waste flows started with wastescapes. However, in line with the consideration of waste as a resource, this research aims towards the co-creation of resource-places or regenerative-scapes. The latter are ecosystems, designed to allow the coevolution of human and nature (Dias, 2015), holding together physical, social and metabolic resources (even wastescapes), in order to re-activate places as resources (Brown et al., 2018).

As in LLs, regenerative design (Mang \& Reed, 2012) is a process-oriented approach, learning from experience and practice. Regenerative design works on the balance within natural cycles, integrating environment and anthropic systems. It promotes a new human-human and human-nature relationship as the ultimate driver of anaIytical and transformational sustainability (Gibbons et al., 2018). This is achieved using innovative technologies aimed at establishing healthier lifestyles and habitats, in coherence with on-going initiatives of the EC towards technological and non-technological eco-innovation. 
In REPAiR pilot cases, material flow analysis of waste management and spatial analysis of wastescapes provide a framework to interpret design and guide actions, applying a system of technologies and strategies with relevant stakeholders and local experts. The aim of the PULLS becomes to facilitate a sustainable transition towards better territorial conditions of welfare, liveability, and cooperation with stakeholders. The shift from waste to resources, through the lens of circular metabolism, becomes the tool to re-interpret and carry out strategies and socio-technical tools in order to mitigate the environmental impact of flows.

\subsection{Integrating the Recycling of Waste and Wastescapes in the PULLS}

In the development of the PULL process, a pre-condition is orienting knowledge co-creation and innovation design: the trust in a public-private-people-partnership where each partner is both competence donor and receiver. At the same time, the cooperation among actors defines specific enabling conditions, supporting the identification of operative tools and envisioning decisionmaking processes.

The recursion of the process becomes an act of legitimacy for its achievements. Positive feedback builds trust among the participants, while serious problems can be driven out through new collaborative and cooperative processes.

PULLs within the two pilot cases of Amsterdam and Naples run in parallel, in a real 'learning by doing' experimentation. Nonetheless, they turned out to be quite different, especially due to the kind of stakeholders involved and their level of awareness about circularity topics. For example, Naples had firstly to overcome institutional mistrust, territorial fragility and spatial injustice before being able to work on the development of EIS. Conversely, Amsterdam could build its experimentations on an already more CE-oriented audience.

Moving towards circularity is urgent for urban planners and decision-makers. Hence, renewing existing technological, socio-political, environmental and economic behaviours and patterns is a necessity. Therefore, when working in LL collaborative environments, such awareness produced different types of responses in various types of contexts and in various categories:

- Products-related innovation, such as the so-called EIS and strategies to implement circularity;

- Process-oriented, such as the development of new decision-making models, collaboratively building interactions and connections within unexpected actors;

- Services-proactive, as the ultimate goal of CoDecision/Co-Governance phases, the mixing between competences and opportunities, in order to increase circularity feasibility.

\section{Conclusion}

In the co-creation approach of the PULLs every stakeholder is involved in the definition of EIS and strategies that aim at improving the quality of life that characterises the investigated territories. This integrated approachwhich is tailored to each specific case study-based on the principles of circularity, is experimented and tested. The PULLs, as an institutional arena for discussions, can facilitate the relations among institutions, citizens, researchers, enterprises and other stakeholders which will eventually constitute new networks of cooperation that can help overcome institutional lock-in situations.

Generally, in urban LLs, stakeholders are actively involved in the development of services and strategies. Moreover, they are also asked to promote actions in the process of their implementation. However, the implementation phase is out of the scope of the project that this article is based on and is therefore not included in it.

In conclusion, with this research, in the PULLs local teams verified EIS and strategies through the lens of existing public programmes and urban planning policies. In this research, PULLs functioned as an empowering tool for local communities influencing decision-making processes. Their ultimate achievement, when the local condition allows, is to become the public arena where the negotiation at the local, regional, and even national level takes place (Attademo \& Formato, 2018). The definition of this 'public arena' guides practical intervention, in parallel with the technical work carried out within institutions. This can help to increase the integration between marginalised population segments and encourage responsibility among citizens and associations, also guaranteeing the efficacy of a transparent process.

The PULLs implemented in the two case studies investigated in this article achieved different outcomes in relation to the following aspects: institutional and social innovation; wastescape definition and regeneration; and circularity.

Specifically, in the PULL of Naples, the solutions and strategies proposed within the PULL workshops were strong enough to stimulate the actual implementation of policies and programs which were overlooked for a very long time, leading to institutional innovation. Social innovation was also achieved as citizens were invited to bring their own perspectives on the territory and its challenges to the PULL workshops, discussing them with experts of the field. These perceptions were then interlinked with the know-how and expertise of citizens who work within the project area. Moreover, PULL participants developed a detailed definition of wastescapes, which was improved thanks to the specific knowledge of the citizens and institutions involved in the PULLs. Finally, in Naples the focus on circularity overcame the sectorial discussion on improving the waste management sector for example by developing innovative waste plants that would be able to face emergency phases (see the case of Land of Fire). 
Instead, circularity was addressed in a systemic way, also involving the social dimension.

In the case of Amsterdam, the PULL workshops applied co-creation between researchers and professionals from the field. Between the workshops, the researchers worked on refining the results from the previous workshop and preparing input for the new workshop. The identified challenges and the objectives that had been defined in the AMA were complex, requiring the development of solutions that need institutional, social and governance innovation to be implemented. An example of this is Circular Tendering as a solution to implement CE principles in large scale building projects. For the market to implement this solution, new taxation policy is needed that favours the use of existing materials and components and relieves taxes on labour. As such, implementing circularity in the construction sector seemed to require complex strategies, involving to a great extent financial-economic and legal aspects, more than the technical aspects that are focused on by many current projects.

On the other hand, several simple circular solutions were found for organic waste, such as the Bread-to-Beer solution, that would be beneficial for both brewers and bakeries. So, whereas simple solutions could be found for implementing a series of circular solutions, a more complex set of strategies is needed to develop the CE systemically, and to make the social and governance changes that are needed to address the most important challenges of the CE.

\section{Acknowledgments}

The authors would like to thank the whole REPAiR Team, and especially the Research Team of the Department of Architecture, University of Naples Federico II, in Italy, and the Team at Delft University of Technology, in the Netherlands. All parts of this article, including the reviewed versions of it, have been written and approved by all of the authors. Specifically, L.A. wrote Section 1 and Section 2.2; A.A. wrote Section 2.1 and Section 2.3.1; H.R. wrote Section 2.3.2; E.F. wrote Section 2.4; L.A. and A.A. wrote Section 2.3 together; L.A. and M.C. wrote Section 4.1 together; L.A., A.A. and H. R. wrote Section 5 together; A.A. and M.C. wrote Section 4.2; G.B. and H.R. wrote Section 2.5 and Section 3.1 together; G.B. and M.F.P. wrote Section 3.2 together.

This research has been carried out within the framework of the European Horizon 2020 funded research REPAiR: REsource Management in Peri-urban AReas: Going Beyond Urban Metabolism. This project has received funding from the European Union's Horizon 2020 research and innovation programme under grant agreement no. 688920 . This article reflects only the authors' view. The Commission is not responsible for any use that may be made of the information it contains.

\section{Conflict of Interests}

The authors declare no conflict of interest.

\section{References}

Amenta, L., \& Attademo, A. (2016). Circular wastescapes. Waste as a resource for periurban landscapes planning. CRIOS, 12(12), 79-88. https://doi.org/10.3280/ CRIOS2016-012008

Amenta, L., \& Formato, E. (2016). Circular planning and adaptive design strategies to recycle wasted landscapes: The peri-urban territories of Campania Plain as a case-study. In C. Hein (Ed.), History Urbanism ResilienCE: Planning and Heritage. Proceedings of the 17th International Planning History Society Conference (pp. 437-448). Retrieved from https://journals.open.tudelft.nl/index.php/iphs/ issue/view/456/IPHS1703

Amenta, L., \& van Timmeren, A. (2018). Beyond wastescapes: Towards circular landscapes. Addressing the spatial dimension of circularity through the regeneration of wastescapes. Sustainability, 10(12). https://doi.org/10.3390/su10124740

Attademo, A. (2015). Being there: Living in the intercultural city. In A. Falotico, N. Flora, F. D. Moccia, M. F. Palestino, S. Pone, F. Rispoli, M. Russo, S. Russo Ermolli, P. Scala (Eds.), Abitare insieme. DDimensione condivisa del progetto contemporaneo dello spazio condiviso di futuro [Living together: The contemporary design of collective spaces] (pp. 186-195). Naples: Clean Edizioni.

Attademo, A., \& Formato, E. (Eds.). (2018). Fringe Shifts. Transforming planning for new suburban habitats. Barcellona: LISTLab.

Berger, A. (2006a). Drosscape: Wasting land in urban America. New York, NY: Princeton Architectural Press.

Berger, A. (2006b). Drosscape. In C. Waldheim (Ed.), The landscape urbanism reader (pp. 198-217). New York, NY: Princenton Architectural Press.

Berruti, G., \& Palestino, M. F. (2017). La pianificazione del ciclo dei rifiuti e delle aree rifiuto nella svolta della governance metropolitana di Napoli [Waste cycle management and wastescapes planning in the transitional phase of metropolitan governance of Naples]. Working Papers. Rivista Online Di Urban@it, 3, 2-11.

Berruti, G., \& Palestino, M. F. (2018). Le aree-rifiuto come sfida dell'economia circolare. Un cantiere aperto nella regione urbana di Napoli [Wastescapes as a challenge for circular economy. A work field in the urban region of Naples]. Urbanistica Informazioni, 278, 26-31.

Berruti, G., \& Palestino, M. F. (2019). Contested land and blurred rights in the Land of Fires (Italy). International Planning Studies. Advance online publication. https://doi.org/10.1080/13563475.2019.1584551 
Brenner, N. (Ed.). (2014). Implosions/explosions: Towards a study of planetary urbanization. Berlin: Jovis.

Brown, M., Haselsteiner, E., Apró, D., Kopeva, D., Luca, E., Pulkkinen, K.-L., \& Rizvanolli, B. V. (2018). RESTORE-SUstainability, restorative to regenerative: An exploration in progressing a paradigm shift in built environmental thinking, from sustainability to restorative sustainability and on to regenerative sustainability (COST Action CA16114 Report). Retrieved from https://www.eurestore.eu/wp-content/ uploads/2018/04/Sustainability-Restorative-toRegenerative.pdf

Cerreta, M., \& Fusco Girard, L. (2017). Smart landscapes. Hybrid decision-making processes for the spatial innovation. Naples: Clean.

Cerreta, M., \& Panaro, S. (2017a). Cilento labscape: A Living Lab approach for local innovation networks. In Proceedings of living cities, liveable spaces: Placemaking and identity. Malta: La Valletta.

Cerreta, M., \& Panaro, S. (2017b). From perceived values to shared values: A multi-stakeholder spatial decision analysis (M-SSDA) for resilient landscapes. Sustainability, 9(7). https://doi.org/10.3390/su9071113.

Cerreta, M., Inglese, P., \& Mazzarella, C. (2018). A hybrid decision-making process for wastescapes remediation. Geodesign, LCA, Urban Living Lab interplay. In A. Leone \& C. Gargiulo (Eds.), Environmental and territorial modelling for planning and design (pp. 603-610). Naples: Federico II Open Access University Press.

Concilio, G., \& Rizzo, F. (2016). Human smart cities. Rethinking the interplay between design and planning. Heidelberg: Springer.

de Leo, D., \& Palestino, M. F. (2017). S-regulation matters. In A. Balducci, V. Fedeli, \& F. Curci (Eds.), Postmetropolitan territories. Looking for a new urbanity (pp. 274-280). New York, NY: Routledge.

de Martino, P. (2016). Land in Limbo: Understanding planning agencies and spatial development at the interface of the port and city of Naples. In C. Hein (Ed.), History Urbanism ResilienCE: Planning and Heritage. Proceedings of the 17th International Planning History Society Conference (pp. 203-216). Retrieved from https://journals.open.tudelft.nl/index. php/iphs/issue/view/456/IPHS1703

Dente, B., \& Coletti, P. (2011). Measuring governance in urban innovation. Local Government Studies, 37(1), 43-56. https://doi.org/10.1080/ 03003930.2010 .548553

Dias, B. D. (2015). Beyond sustainability: Biophilic and regenerative design in architecture. European Scientific Journal, 7881(March), 1857-7881.

EC. (2009). Living Labs for user-driven open innovation. Luxembourg: Office for Official Publications of the European Communities.

EC. (2010). Being wise with waste: The EU's approach to waste management. Luxembourg: Publications Office of the European Union.

EC. (2012). Eco-innovation the key to Europe's future competitiveness. Luxembourg: Environment, Publications Office. https://doi.org/10.2779/68837

EC. (2014). Towards a circular economy: A zero waste programme for Europe. Luxembourg: Publications Office of the European Union.

EC. (2016). REPAiR-REsource Management in Periurban AReas: Going beyond urban metabolism. European Commission. Retrieved from https://cordis. europa.eu/project/rcn/203259/factsheet/en

EC Horizon 2020. (2019). Waste: A resource to recycle, reuse and recover raw materials. Europa. Retrieved from https://ec.europa.eu/programmes/ horizon2020/en/h2020-section/waste

EEA European Environment Agency. (2015). Waste prevention: where do European countries stand? European Environment Agency.

Ellen MacArthur Foundation. (2015a). Growth within: A circular economy vision for a competitive Europe. Cowes: Ellen MacArthur Foundation. Retrieved from https://www.sun-institute.org/wc/files/growth_ within_for_print1.pdf

Ellen MacArthur Foundation. (2015b). Towards a circular economy: Business rationale for an accelerated transition. Cowes: Ellen MacArthur Foundation. Retrieved from https://www.ellenmacarthur foundation.org/assets/downloads/TCE_EllenMacArthur-Foundation_9-Dec-2015.pdf

ENoLL. (2016). The first step towards a new innovation system. Open Living Labs. Retrieved from http:// www.openlivinglabs.eu

ENoLL, \& World Bank. (2015). Citizen-driven innovation. A guidebook for city mayors and public administrators. Washington, DC: The World Bank.

European Commission. (2018). Circular economy. Implementation of the circular economy action plan. Europa. Retrieved from http://ec.europa.eu/ environment/circular-economy/index_en.htm

Formato, E., Attademo, A., \& Amenta, L. (2017). REPAiR "wastescape" e flussi di rifiuti: Materiali innovativi del progetto urbanistico [REPAiR wastescapes and waste flows: Innovative materials for urban design]. Urbanistica Informazioni, March/April(272), 956-963.

Gibbons, L., Cloutier, S., Coseo, P., Barakat, A., Gibbons, L. V., Cloutier, S. A., Barakat, A. (2018). Regenerative development as an integrative paradigm and methodology for landscape sustainability. Sustainability, 10(6), 1910. https://doi.org/10.3390/su10061910

Innovation Alcotra. (2013). La creazione di Living Lab transfrontalieri [The design of transboundary Living Lab]. Torino: Piemonte Region.

Mang, P., \& Reed, B. (2012). Designing from place: A regenerative framework and methodology. Building Research and Information, 40(1), 23-38. https://doi. org/10.1080/09613218.2012.621341

O’Shea, C., Hegeman, L., \& Bennett, C. (2016). Logistical ecologies of the North American operational landscape. MAS Context: Hidden, 28, 8-35.

Oswalt, P., \& Rieniets, T. (2006). Atlas of shrinking 
cities/Atlas der schrumpfenden städte. Ostfildern: Hatje Cantz Pub.

Palestino, M. F. (2015). How to put environmental injustice on the planner's radical agenda. Learning from the Land of Fires, Italy. In M. Mancoun \& K. Maier (Eds.), Proceedings from the 29th Annual AESOP Congress Definite space, fuzzy responsibility (pp. 2576-2586). Prague: Czech Technical University.

PBL Planbureau voor de Leefomgeving. (2018). Achtergrondrapport circulaire economie in kaart [Map of the circular economy background report]. The Hague: PBL. Retrieved from https://www.pbl.nl/publicaties/ achtergrondrapport-circulaire-economie-in-kaart

Pollitt, C., Bouckaert, G., \& Loeffler, E. (2006). Making quality sustainable: Co-design, co-decide, coproduce, co-evaluate, 4QC. Paper presented at Conference for Public Administration in the EU, Finland.

REPAiR. (2017a). D6.3: Decision model pilot studies. H2020 REPAiR. Retrieved from http://h2020repair. eu/wp-content/uploads/2018/01/Deliverable_6.3_ Decision_model_for_Pilot_cases.pdf

REPAiR. (2017b). D6.1: Governance and decision-making processes in pilot cases. H2020 REPAiR. Retrieved from http://h2020repair.eu/wp-content/uploads/ 2017/09/Deliverable_6.1_Governance_and_ Decision-Making_Processes_in_Pilot_Cases.pdf

REPAiR. (2017c). D3.1: Introduction to methodology for integrated spatial, material flow and social analyses (REPAiR Report). Retrieved from https:// repository.tudelft.nl/islandora/object/uuid:1e60fd65697a-406e-be4e-dd849c180170?collection=research

REPAiR. (2017d). D5.1: PULLs handbook (REPAiR Report). Retrieved from https://repository.tudelft.nl/ islandora/object/uuid:e23a0980-558b-4963-ab1e13e139867de1?collection=research

REPAiR. (2018a). D5.3: Eco-innovative solutions Naples (REPAiR Report). Retrieved from http://h2020repair. eu/project-results/project-reports/

REPAiR. (2018b). D5.4: Handbook: how to run a PULL. H2020 REPAiR. Retrieved from http://h2020repair. eu/wp-content/uploads/2019/03/Deliverable-5.4Handbook-how-to-run-a-PULL.pdf

REPAiR. (2018c). D3.3: Process model for the two pilot cases: Amsterdam, the Netherlands, \& Naples, Italy. H2020 REPAiR. Retrieved from http://h2020repair. eu/wp-content/uploads/2019/05/Deliverable-3.3-

Process-model-for-the-two-pilot-cases-Amsterdamthe-Netherlands-and-Naples-Italy.pdf

Rigillo, M., Amenta, L., Attademo, A., Boccia, L., Formato,
E., \& Russo, M. (2018). Eco-innovative solutions for wasted landscapes. Ri-Vista, 16(1), 146-159. https:// doi.org/http://dx.doi.org/10.13128/RV-22995

Russo, M. (Ed.). (2014). Urbanistica per una diversa crescita. Progettare il territorio contemporaneo. Una discussione della Società italiana degli urbanisti [Urbanism for a different growth. Design contemporary landscape. A discussion of Italian Society of Urbanists]. Roma: Donzelli Editore.

Russo, M. (2017). Abitare Insieme. II progetto contemporaneo dello spazio condiviso [Living together. The contemporary design of collective spaces]. Naples: Clean Edizioni.

Secchi, B. (2010). A new urban question. Understanding and planning the contemporary European city. Territorio, 53, 22-23.

Secchi, B. (2013). La città dei ricchi e la città dei poveri [The city of rich people and the city of poor people]. Bari: Editori Laterza. Retrieved from https://www. laterza.it/index.php?option=com_laterza\&ltemid= 97\&task=schedalibro\&isbn $=9788858106648$

Ståhlbröst, A., \& Holst, M. (2012). The Living lab methodology handbook. Luleå: Social Informatics, Luleå University of Technology, and the Centre for DistanceSpanning Technology.

Steen, K., \& van Bueren, E. (2017). Urban Living Labs. A living lab way of working. Amsterdam: Amsterdam Institute for Advanced Metropolitan Solutions, Delft University of Technology. Retrieved from https:// www.ams-amsterdam.com/wordpress/wp-content/ uploads/AMS-Living-Lab-Way-of-Working_small.pdf

Steinitz, C. (2012). A framework for geodesign. Changing geography by design. New York, NY: Esri Press.

UNEP (2011). Decoupling natural resource use and environmental impacts from economic growth (Report of the Working Group on Decoupling to the International Resource Panel). Nairobi: UNEP.

van de Ven, F. H. M., Gehrels, H., van Meerten, B., van de Pas, E., Ruijgh, D., Vatvani, N., . . van der Linden, T. (2009). Land \& water management in the urban environment. Utrecht and Delft: Publisher.

Wandl, A., Nadin, V., Zonneveld, W., \& Rooij, R. (2014). Beyond urban-rural classifications: Characterising and mapping territories-in-between across Europe. Landscape and Urban Planning, 130, 50-63.

Williams, J. (2019). Circular cities. Urban Studies, 56, 2746-2762. https://doi.org/10.1177/004209801880 6133

\section{About the Authors}

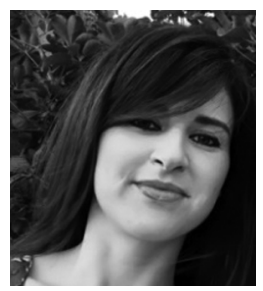

Libera Amenta is a Post-Doc Researcher in the Department of Architecture at the University of Naples Federico II, Italy. She has been, until recently, also a Post-Doc Researcher in the Department of Urbanism at TU Delft, the Netherlands. Since 2016, she has been carrying out research on topics regarding the circular regeneration of wastescapes as a member of the EU-funded Horizon 2020 REPAiR project. 

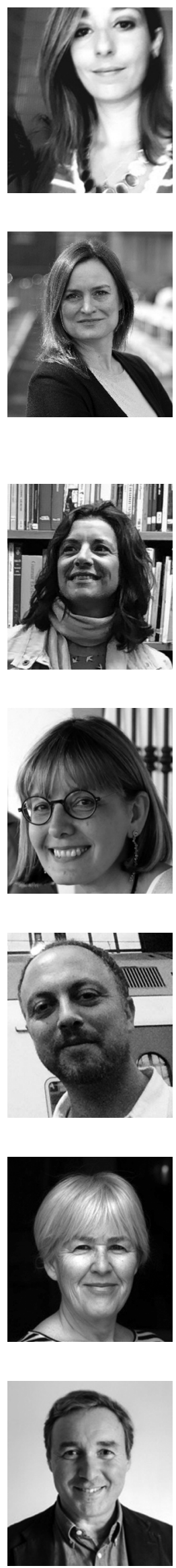

Michelangelo Russo is the Dean of the Department of Architeture, University of Naples Federico II, where he is Full Professor of Urbanism. He coordinated-from 2013 until recently-the Doctorate School in Architecture in the same Department. He has been carrying out so far several funded research of national and international interest. He was from 2014 until 2018 the head of the Italian Society of Urbanists (SIU). Today he is the leader of the Neapolitan Team of the European project Horizon 2020 entitled: "REPAiR-Resource Management in Peri-urban Areas: Going Beyond Urban Metabolism". 